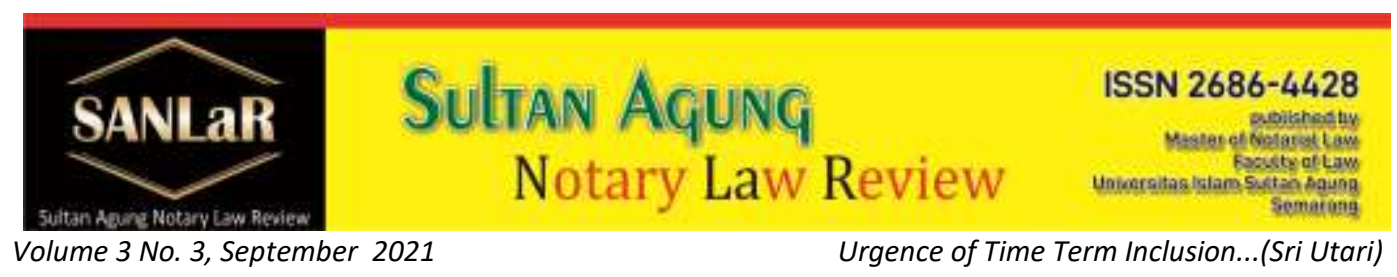

\title{
Urgence of Time Term Inclusion in Fulfillment of Rights \& Obligations the Parties in Transaction Agreement
}

\section{Sri Utari ${ }^{*}$}

$\left.{ }^{*}\right)$ Faculty of Law, Universitas Islam Sultan Agung (UNISSULA) Semarang, E-mail: sriutari2021@gmail.com

\begin{abstract}
The binding agreement for the sale and purchase of land rights is a preliminary agreement made by the prospective seller and prospective buyer before the signing of the deed of sale and purchase before the PPAT. The contents are about the sale and purchase of land rights, but the format is only limited to a binding agreement made by a notary. The Sale and Purchase Binding Agreement is not specifically regulated, so the form and content vary according to the agreement of the parties who made it. However, in its implementation it is often not in accordance with what has been agreed, therefore it is necessary to have special rules so that the parties get legal certainty and protection. The purpose of writing is to describe and analyze the importance of setting the time period as well as the legal consequences that arise by not including the time limit of the rights and obligations of the parties involved. parties to the deed of agreement to bind the sale and purchase of land rights made before a notary. The method used in this study is a normative juridical approach using secondary data sources. The data collection technique used is literature study, then analyzed by qualitative analysis method using legal protection theory, legal certainty theory and justice theory. From the results of the research, it is concluded that: 1 . The importance of the rules set by the government to specifically regulate the sale and purchase agreement deed so that the form of the deed made by a notary can provide legal certainty and protection. 2 . The legal consequences of the absence of strict legal rules regarding the deed of agreement to bind the sale and purchase of rights to the land.
\end{abstract}

Keywords: Urgency; Sale; Purchase; Agreement; Transaction.

\section{Introduction}

Soil is one of the important objects in human survival. The increase in the number of people is directly proportional to the increase in human need for land as a place to live or be used for economic activities. However, the importance of the value of land for the community, makes land one of the objects that are 
prone to dispute, because it requires special regulations governing land. Previously, before Act No. 5 of 1960 concerning the Basic Agrarian Basic Regulations (hereinafter referred to as the LoGA) was made, the regulation on land has not yet been unified. Act No.

The acquisition of land rights requires a certain process or mechanism, for example due to inheritance, grants, buying and selling, and so on. In the event that the acquisition is through a sale and purchase transaction, a grant and the acquisition of rights that require a deed to be made, then it is done before the PPAT (Land Deed Making Officer) in order to carry out the transfer along with the registration of the land at the land office so that legal certainty can be achieved, as regulated in the UUPA. . In addition to the UUPA regarding land registration, it is also regulated in PP No. 24 of 1997, in which one of the objectives of land registration is to establish an orderly administration.

Article 3 paragraph (1) of PP No. 37 of 1998 states that to carry out this main task, PPAT is given the authority to make authentic deeds regarding all certain legal actions regarding land rights and property rights to flats located in their working areas. The intended authentic deed is as evidence that will be used as the basis for land registration, both for the first time registration and maintenance of land registration data.

One way of acquiring land that is often done is by buying and selling. In buying and selling there are two legal subjects, namely the seller and the buyer, each of whom has rights and obligations, so they are each in some respects the party carrying out the obligations, and in other cases the party receiving the rights. This relates to the reciprocal nature of the sale and purchase agreement (werdering overeenkomst). ${ }^{1}$

In practice, it often happens that the parties who want to make a sale and purchase cannot meet the conditions for a sale and purchase at one time. To overcome this, and for the smooth and orderly administration of land, a legal innovation is found, namely the making of a Sale and Purchase Binding Agreement. (PPJB). The Sale and Purchase Binding Agreement is a preliminary agreement that 1 aims to bind the parties until the sale and purchase requirements are fulfilled and a sale and purchase can be made before the PPAT. The problem that is often encountered in the PPJB deed is because one of the parties in the Sale and Purchase Agreement is negligent in not fulfilling the obligations as agreed in the PPJB Deed, where the non-fulfillment of achievements by one of the parties causes losses to the other party, for that there is a need for arrangements specifically regarding the form of the PPJB Deed, so that the PPJB deed that has been made and agreed upon by the parties can be carried out properly and can provide legal protection and certainty for the parties who made it.

\footnotetext{
${ }^{1}$ Idris Zainal, Ketentuan Jual Beli Memuat Hukum Perdata, Fakultas USU Medan, 2004, p.36
} 


\section{Research Methods}

The method used in this study is a normative juridical approach to reviewing the applicable laws and regulations. This study uses several approaches, namely: the statute approach, this approach is carried out by examining the legislation and conceptual research (conceptual approach), with this approach the author will use the views and doctrines that have developed in the science of law. ${ }^{2}$ This writing uses a qualitative descriptive technique, meaning that with this technique the author seeks to describe the legal issues raised, then analyzed to find solutions through legal materials that have been inventoried. After being analyzed by the deductive method, based on general and relevant legal principles and principles, general conclusions will be found and then converging as conclusions on answers or concrete solutions to the legal problems studied.

\section{Results and Discussion}

3.1. The urgency of the inclusion of a period of time in Fulfilling the Rights and Obligations of the Parties in the Deed of Binding Agreement on the Sale and Purchase of Land Rights Made before a Notary

In conducting the sale and purchase of land rights, a Sale and Purchase Deed should be made before the PPAT, as evidence of the transfer of rights from the seller to the buyer. Government Regulation Number 24 of 1997 concerning Land Registration and Government Regulation Number 37 of 1998 concerning the Regulation of the Position of the Maker of Land Deeds (PPAT), it is regulated that in carrying out the sale and purchase of land rights must be carried out in the presence of an authorized official, in addition to the deed of transfer of rights ( the sale and purchase deed) is also made by the Land Deed Making Officer (PPAT) and the sale and purchase deed is an authentic deed whose form and content are based on the applicable laws and regulations.

Before making a sale and purchase before the Land Deed Making Officer (PPAT), there are several requirements that must be met by the parties who will carry out the sale and purchase, such as: land rights to be traded are legal rights that are owned and proven by the existence of a land certificate. or other legal evidence, the sale and purchase has been paid in full and all taxes related to the sale and purchase (SSP and BPHTB) have also been paid by the parties. After all these things are completed or fulfilled, then the parties who will carry out the sale and purchase of land can make a sale and purchase of land rights and make a deed of sale and purchase of land in front of the Land Deed Maker Official

\footnotetext{
${ }^{2}$ Peter Mahmud, Metode Penelitian Hukum, KencanaPredana Media Group, Jakarta, 2005, p. 96119
} 
(PPAT) and then register the land for the transfer of rights. . However, if these conditions are not met,

Such a situation, of course, does not benefit the parties who will buy and sell land rights. On the one hand, the seller must postpone the process of selling the land until all these conditions can be met. The same is true for the buyer, who also has to postpone his desire to acquire land rights. To overcome this, and in order to smooth the orderly land administration, a Deed of Sale and Purchase Binding Agreement (PPJB) was made. The Sale and Purchase Binding Agreement is an assistance agreement that functions as a preliminary agreement and is free in form. The PPJB deed made before a notary is binding on the parties, contains the promises of the parties, and creates a legal relationship in the form of rights and obligations for the parties who make it.

An authentic deed as explained in Article 1868 of the Civil Code which reads: "An authentic deed is a deed in the form determined by law made by or before public officials in power for that at the place where the deed was made. ." From Article 1868 of the Civil Code mentioned above, it can be seen that for an authentic deed the form of the deed is determined by law and must be made by or before an authorized employee. Authorized employees referred to here include notaries,

So in accordance with the provisions stipulated in Article 1868 of the Civil Code, it is stipulated or it can be stated that the requirements for an authentic deed are as follows:

a. the deed must be made "by" (door) or "in front of" (ten overstaan) a public official;

b. the deed must be made in the form determined by law;

c. public officials by or before whom the deed was made, must have the authority to make the deed.

Based on the information above, it can be seen that in the Sale and Purchase Binding Agreement Deed (PPJB), which was made before or by a Notary, the Sale and Purchase Binding Agreement (PPJB) deed became an authentic deed. Because it has been made before or by an authorized official (one of them is a notary) so that it has fulfilled the provisions or conditions regarding an authentic deed, namely the deed must be made "by" (door) or "in front of" (ten overstaan) a public official.

The PPJB deed made by the parties is an Authentic Deed, where the deed has at least the power of proof against the parties who have agreed with it with 
absolute power of proof. If a dispute arises between the parties, then what is contained in the authentic deed is perfect evidence so that there is no need to prove it with other evidence. However, even though the parties have agreed but in an agreement that has been made, often in its implementation it always does not go according to what has been agreed upon by the parties who made it, there are certain conditions that result in an agreement having to end not in accordance with the initial agreement.

What often happens in the PPJB deed is the non-fulfillment of the obligations of the parties, such as the untimely payment made by the buyer to the seller, the absence of a certificate of land rights as proof of ownership that should be submitted by the seller, or the obligation to pay the transfer of rights tax by the parties. For example, in the Sale and Purchase Binding Deed Number 02, dated July 1, 2016, made before a Notary in Semarang City. The PPJB deed made by the parties is the PPJB deed in full, but because the certificate of land rights is still in the process of being resolved at BPN by the Seller/Developer, the Sale and Purchase Deed cannot be made. In Article 4 (four) the PPJB deed contains the implementation of the Sale and Purchase Deed, the article reads "If the process of splitting the master certificate has been completed, the Deed of Sale and Purchase will be made in front of the Land Deed Maker Official (PPAT)". The article states that the implementation of the making of the Sale and Purchase Deed will be carried out before the PPAT if the process of splitting the Master Certificate has been completed without clearly and in detail mentioning the period or date of completion of the splitting of the Certificate. The time period or date of completion of the certificate solving here serves so that the parties understand the deadline for the completion of the certificate solving that must be carried out by the seller. In addition to having a function to understand each other, this is to ensure legal certainty for buyers to be able to immediately make a Deed of Sale and Purchase before the PPAT on the land that has been purchased from the seller, so that the buyer can obtain proof of ownership rights to the land. The omission of the last date of completion of the certificate split by the seller makes the buyer not get legal certainty. According to the author, in the stages of completing the certificate split which has been stated in the deed, it must contain details regarding the time period/date of completion of the certificate split carried out by the seller. Along with this, in making the deed, the buyer has the right to request a sanction clause to the notary to be written on a deed if the seller is unable to complete the certificate solving process in a timely manner. The author is of the opinion that in article 4 (four) of the PPJB Deed above, it only contains an agreement to make a Sale and Purchase Deed before the PPAT which will only be carried out, even though the PPJB deed made by the parties is a paid PPJB deed, then there should be a special clause regarding sanctions governing the seller's obligation to fulfill his achievements to the buyer, which states "If the seller is unable to fulfill his obligations within the 
specified period, which negligence has occurred and is proven by the passage of time, the seller is subject to a fine of the agreed amount of the amount to be paid by the seller to the buyer, for each day of delay. The fine must be paid immediately and in full." which states "If the seller is unable to fulfill his obligations within the specified time period, which negligence has occurred and is proven by the passage of time, the seller is subject to a fine of the agreed amount of the amount to be paid by the seller to the buyer, for each every day of delay. The fine must be paid immediately and in full."

In addition to the things above, the PPJB deed made in full of course raises the question of why the PPJB deed is made if the payment made by the buyer has been paid off. The results of interviews conducted by the author at the Semarang City Notary's office there are several conditions that cannot be met, namely, the object is still used by the seller, the seller or buyer tax has not been paid, checking the certificate of land rights related to the certainty of land ownership by the seller at the National Land Agency, and Objects under Bank guarantee. From some of the reasons described above, there are reasons that according to the author violate the rules, namely objects in bank guarantees, this has violated the rule that objects that are guaranteed cannot be traded.

When the buyer purchases a land right, the date of the PPJB deed must be stated. The PPJB deed must also clearly state the time/date of the Sale and Purchase Deed to be executed before the PPAT, this is to ensure legal certainty for the buyer to have perfect land rights. The buyer's right is not only to enjoy the physical land and buildings on it, but also to documents, especially certificates. Because with these letters, the buyer gets legal certainty to own and control the land he bought.

The PPJB deed is an authentic deed that will not be disputed if one of the parties does not object or is harmed, but with the contents of the PPJB deed above, it is very possible for a dispute to arise that is disputed by one of the parties. So according to the author, the formulation of the period for fulfilling the rights and obligations in the deed is very important and must be detailed correctly. The formulation of the time period in the PPJB deed is also related to sanctions if the binding agreement is violated by the parties. The two clauses can provide legal certainty for the parties after facing a notary. By including a clause on the fulfillment of the rights and obligations in detail and clearly, the termination of the agreement will also be carried out automatically. Thus the parties can feel safe and do not hesitate to make a PPJB deed before a notary. In the PPJB deed, it should clearly state the sanctions for the parties if they default, so that it can encourage the parties to perform according to what has been agreed in the agreement. In addition, according to the author, there needs to be special arrangements by the government regarding the Sale Binding Deed. Purchases 
made before a notary, so that they can provide legal protection and certainty for the parties who make them. 


\subsection{Legal Consequences That Arise From Not Including the Time Limit for Fulfillment of the Rights and Obligations of the Parties in the Deed of Sale and Purchase Binding Agreement (PPJB) made before a notary?}

Article 1868 of the Civil Code explains that "an authentic deed is a deed in the form determined by law made by or before public officials who have power for that at the place where the deed was made.

As evidence, an authentic deed is said to have perfect evidentiary power because it has three powers of proof, namely the power of outward proof, the power of formal proof, and the power of material proof. The power of outward proof / uitwendige bewijskracht is the ability possessed by an authentic deed to prove its validity as an authentic deed that was born in accordance with the legal rules regarding the requirements of an authentic deed. The power of formal proof / formelebewijskracht, namely the ability to provide certainty that an event and deed mentioned in the deed were indeed carried out, related to the date or time of manufacture, the identity of the parties, the signatures of the appearers, witnesses, and notaries, the place of making the deed, as well as information or statements seen, witnessed, heard or conveyed by the parties. The strength of material proof / materialelebeswijskarcht, is a certainty regarding the material truth of a deed.

Authentic deeds can be further divided into 2 (two) types, namely:

1. deed made by the official (relaas deed) and

2. Deed made by the parties (partij deed).

Relaas deed is a deed made by an official who is authorized to do so, in which the official explains what he saw and what he did. So the initiative comes from the official himself and not from the person whose name is listed in the deed. ${ }^{3}$ An example is the Deed of Minutes or Minutes of Meeting of the GMS or a limited liability company. While Partij deed is a deed made by an official at the request of interested parties. So even though the person making the deed is the authorized official, the initiative comes from the interested parties. ${ }^{4}$ Partij deed contains a description of what is explained by the parties who appear before a notary, for example is the Deed of Sale and Purchase Binding Agreement (PPJB).

The PPJB deed made before a Notary is included in the type of "Partij Deed", where the deed contains the will of the parties, what is stated in the PPJB deed is

\footnotetext{
${ }^{3}$ R. Soeroso, Perjanjian Dibawah Tangan Pedoman Praktis Pembuatan Dan Aplikasi Hukum, Ed. II, Sinar Grafika, Jakarta, 2010, p. 8-9.

${ }^{4}$ Ibid
} 
an agreement from the parties who made it. The PPJB deed generally contains the object of sale and purchase, the price and method of payment, guarantees, promises and the rights and obligations of the parties. In addition to these things, the clause regarding the period of fulfillment of rights and obligations is very important to be included in the PPJB deed, it is often found that the sale and purchase binding deed does not contain in detail and clearly the timeframe or date of fulfillment of the rights and obligations of the parties, this will certainly create uncertainty for the parties to obtain their rights and obligations. In the process, often a deed of agreement does not go according to the agreement of the parties who made it, there are conditions that result in an agreement having to end not in accordance with the initial agreement. A deed will be a problem if one of the parties does not fulfill its achievements or one of the parties feels aggrieved, therefore it is very necessary to explain clearly and in detail what the parties have agreed on in making the PPJB deed, so that the PPJB deed can provide legal certainty and protection for those who made it.

The buyer has the main obligation to pay the price of what he bought, at the time and place as determined according to the agreement/agreement concerned with the additional rule that if the parties do not specify, the payment must be made on the spot at the time of delivery of the object. Legal protection for the seller in the PPJB deed can be formulated by the prospective seller himself, usually in the form of requirements requested by the prospective seller himself. For example, in the sale and purchase binding agreement, the seller asks the buyer to make payments within a certain period of time accompanied by cancellation conditions and sanctions for late payments where the cancellation of the sale and purchase agreement the seller will not return the money that has been paid by the buyer because in this case the buyer is considered to have defaulted. The policy made by the seller is one of the sanctions given by the seller to the prospective buyer because the buyer cannot fulfill his obligations which is also a form of the seller's efforts to obtain legal certainty and protection.

Similarly, protection for buyers. The buyer can also provide requirements to the seller, the goal is that if the seller does not fulfill his obligations, the buyer can sue and ask for compensation in accordance with the agreement stipulated in the sale and purchase binding agreement that has been made by both parties. Whereas in paid PPJB, in addition to providing conditions to the seller, a request for authorization from the seller to the buyer can be followed which cannot be withdrawn. It is possible that fulfilling all the requirements agreed in the salepurchase agreement will take quite a long time, so that it is also possible for the prospective seller to be unable to sign the sale and purchase deed (AJB).

To avoid this, usually the buyer in the sale-purchase agreement will ask to make a deed of power from the seller in which it contains provisions if the seller is 
unable to attend while all the terms and conditions agreed in the sale-purchase binding agreement have been fulfilled, and can be done signing of the deed of sale and purchase, the seller will authorize the buyer to appear in person and sign the deed of sale and purchase on behalf of the seller before the PPAT.

The PPJB deed is a type of reciprocal agreement where the rights and obligations are on both parties, each party has the main obligation to perform achievements in accordance with the agreement made between the two. If the parties to an agreement cannot fulfill their obligations in accordance with what was agreed in the agreement they have made, then the party is said to have defaulted. Abdulkadir Muhammad, in his book "Indonesian Civil Law" writes that default means not fulfilling the obligations that have been agreed upon in the engagement. ${ }^{5}$ Default (negligence equals negligence) of one of the parties in the agreement there are 4 (four) categories:

a. Doesn't do what it's supposed to do

b. Carry out what it promised, but not as promised

c. Carry out what it promised but not on time

d. Carry out something that according to the agreement is forbidden to do. ${ }^{6}$

There are two possible reasons for not fulfilling this obligation, namely: ${ }^{7}$

a) The debtor's fault, either on purpose or by negligence

b) There is force majeure, so it is beyond the ability of the debtor and the debtor is not guilty.

Failure to fulfill the performance by the debtor is generally a breach of the promise of default, but if the performance is not fulfilled by the debtor there is an event beyond his capabilities, is it also a default and the occurrence of the loss must be held accountable by the debtor, so that if the performance is not fulfilled in a certain situation or conditions beyond the ability, it is called a state of coercion or overmacht. ${ }^{8}$

A state of coercion is a condition that occurs after the agreement is made, which prevents the debtor from fulfilling his achievements. The situation cannot be blamed and does not have to bear the risk, and it was not considered by the parties at the time of making the agreement. So the debtor does not fulfill the achievement because there is no mistake and the forced circumstances cannot

\footnotetext{
${ }^{5}$ Abdulkadir Muhammad, Hukum Perdata Indonesia print-5, Citra Aditya Bakti, Bandung, 2014 p.241.

${ }^{6}$ R. Subekti, Op.Cit, p.45.

${ }^{7}$ Abdulkadir Muhammad, Hukum Perikatan, Citra Aditya Bakti, Bandung, 1992, p. 43.

${ }^{8}$ Achmad Busro, Hukum Perikatan Berdasar Buku III KUH Perdata, Percetakan Pohon Cahaya, Yogyakarta, 2011, p. 34.
} 
be held accountable by the debtor..$^{9}$ As regulated in Articles 1244 and 1245 of the Civil Code.

The consequences arising from default are the obligation or obligation for the debtor to pay compensation, or in the presence of a default by one party, the other party can demand the cancellation of the agreement. Provisions regarding this compensation have been stipulated in Article 1243-1252 of the Civil Code. From the provisions of the article it can be concluded that what is meant by compensation is a sanction that can be imposed on a debtor who does not fulfill the performance in an agreement to provide reimbursement of costs.

Basically the compensation that can be claimed by the aggrieved party (creditor) is only a loss in the form of a sum of money, the compensation must be in the form of money. Compensation that can be claimed is compensation which is a direct result of default. The compensation requested must be appropriate. The appropriateness is aligned with the nature of the agreement by taking into account the losses actually suffered by the creditor.

Regarding negligence or default on this debtor, it must be stated in advance by giving a warning or subpoena. In general, the content of the subpoena is a warning from the creditor so that the debtor excels from the agreement made (the basis for a warning from the creditor).

By defaulting / breaking a promise, the cancellation condition has occurred. With the cancellation condition, the aggrieved party can sue for cancellation. As stated in Article 1266 of the Civil Code "Breaking a promise is a condition for cancellation". Article 1266 paragraph (1) of the Civil Code, the conditions for cancellation are considered to be included in a reciprocal agreement, if one of the parties in the agreement reneges on what has been agreed. Article 1266 paragraph (2) of the Civil Code states that to cancel an agreement, it must be by a judge's decision. Furthermore, Article 1266 paragraph (3) of the Civil Code stipulates that a request for cancellation must be made even though the conditions for cancellation have been stated in the agreement. If the void condition occurs, the agreement is not void from a legal point of view. in the sense that the agreement will not be canceled by itself, but the cancellation must be requested to the judge. The request must also be made even though breaking the promise as a condition for cancellation is included in the agreement. ${ }^{10}$

If the parties, either the seller/developer or the buyer, choose to settle a dispute in court, the party filing the lawsuit must as much as possible prove that the opponent has defaulted, not an overmacht. Likewise with the party being sued,

\footnotetext{
${ }^{9}$ Ibid.

${ }^{10}$ Mariam Darus Badrulzaman, Aneka Hukum Bisnis, Alumni, Bandung, 2005, p.13.
} 
he must convince the judge if the fault does not lie with him, with a defense such as coercive circumstances, stating that the buyer has waived his rights, and the buyer's negligence.

Against the negligence or negligence of the debtor as a party who is obliged to do something, several sanctions or penalties are threatened. There are four kinds of punishments or consequences received by negligent debtors, namely: ${ }^{11}$

1. Paying losses suffered by creditors or briefly called compensation.

2. Cancellation of the agreement or also called breaking the agreement.

3. Risk transfer.

4. Pay the court fee, if it is brought before a judge.

Therefore, in a PPJB it must be stated clearly regarding the period of fulfillment of rights and obligations as well as the sanctions given if one of the parties is declared in default. This is a prevention if in the future there is a dispute between the parties. So, the consequences resulting from the cancellation of the PPJB made before a notary due to default are:

1) There is a fine that must be paid by the party committing the act of default.

2) The deed made before a notary, namely the PPJB deed, can be canceled if it does not meet the subjective element or is null and void if it does not meet the objective element.

3) Pay the court fees if the cancellation of the PPJB is carried out before the court.

Default is one of the violations included in the subjective requirements in Article 1320 of the Civil Code. Thus the cancellation must go through a report from one of the aggrieved parties to the police for further action, the reporting is aimed at obtaining a judge's decision or decision regarding the PPJB deed made.

According to the author, PPJB should be able to proceed well, as written in one of the articles in the PPJB deed which states "Regarding matters that have not been regulated or sufficiently regulated in this deed, it will be resolved further by deliberation and consensus between the two parties". By containing clauses of sanctions and fines and in good faith from the parties, the agreement will be carried out properly, the parties will carry out the agreement seriously and with respect to disputes that may occur, the parties can resolve the dispute properly by deliberation and consensus, Thus, the legal consequences of the cancellation of the Deed of Binding Sale and Purchase of Land Rights caused by default by one of the parties can be carried out without having to go through a lawsuit process. The party who defaults may be subject to a fine the amount of which has been

\footnotetext{
${ }^{11}$ Yahya Harahap, Segi-segi Hukum Perjanjian, Second Edition, Alumni, Bandung, 1986, p. 56
} 
agreed upon by the parties for each day of delay. The fine must be paid immediately and at once to the injured party, if the problem has not been resolved, the parties request a judge's decision who has the authority to decide the rights and obligations of the parties.

\section{Conclusion}

The binding agreement for the sale and purchase of land rights as a preliminary agreement before the deed of sale and purchase before the PPAT must contain a time period clause related to the fulfillment of the rights and obligations of the prospective seller and prospective buyer, besides that the PPJB deed must also contain a clause relating to sanctions if the binding agreement This is violated by prospective sellers and prospective buyers, because by writing explicitly the time period clause and sanctions in the PPJB deed, the parties get legal certainty and the interests of the parties can also be protected. And the legal consequence of not including the time limit for fulfilling the rights and obligations of the parties from the deed of binding sale and purchase of land rights, namely the parties who default can be subject to a fine of the agreed amount of the amount that must be paid by the party who defaulted to the other party for each every day of delay. The fine must be paid immediately and all at once. The aggrieved party can also request a judge's decision to be able to decide on the rights and obligations of the parties, and request the cancellation of the PPJB deed made by the parties.

\section{References}

Journals:

[1] A Chuasanga, Ong Argo Victoria. (2019). Legal Principles Under Criminal Law in Indonesia Dan Thailand, Jurnal Daulat Hukum, Vol 2, No 1 (2019) http://jurnal.unissula.ac.id/index.php/RH/article/view/4218

[2] Alam, Bahrul., \& Khisni, Akhmad. (2020). Legal Protection of Holders of Land Loss Data In The City Land Office of Kendari. JURNAL AKTA: Vol.7, No. 2, 159-164. Retrieved from http://jurnal.unissula.ac.id/index.php/akta/article/view/7963

[3] Arrohim, Mohammad B., \& Wahyuningsih, Sri Endah. (2020). Analysis of Judicial Application of Criminal Penalty Against Notary / Land Deed Officials Conducting Making Crime of the Fake Authentic Deed in State Court of Semarang. JURNAL AKTA: Vol.7, No. 2, 183-188. Retrieved from http://jurnal.unissula.ac.id/index.php/akta/article/view/7891

[4] Deen, Thaufiq., Ong Argo Victoria \& Sumain. (2018). Public Notary Services In Malaysia. JURNAL AKTA: Vol. 5, No. 4, 1017-1026. Retrieved from http://jurnal.unissula.ac.id/index.php/akta/article/view/4135 
[5] Ong Argo Victoria, (2018) Waqf Al-Nuqūd In Indonesia (In Law Perspective), Jurnal Pembaharuan Hukum Vol 5, No 1 Universitas Sultan Agung, http://jurnal.unissula.ac.id/index.php/PH/article/view/2999

[6] Sukarmi, S., \& Victoria, A. (2018). Cash Waqf in Sustaining Of Indonesian Society "In Legal \&amp; Economic Perspective". AL-ITQAN: JOURNAL OF ISLAMIC SCIENCES AND COMPARATIVE STUDIES, 2(1), 83-97. https://doi.org/10.31436/al-itqan.v2i1.43

[7] Victoria, O. A., \& ., M. (2021). Doctor's Constributions in Transportation Monitoring During COVID-19 Pandemic. KnE Social Sciences, 5(1), 598618. https://doi.org/10.18502/kss.v5i1.8317

[8] Hartanto, H.; Victoria, O.A.; Chuasanga, A. Maritime Transportation in Indonesian Policy. J. Pembaharuan Huk. 2019, 6, 36-44, Jurnal Pembaharuan Hukum Unissula, Vol. 6, No. 1 (2019), http://jurnal.unissula.ac.id/index.php/PH/article/view/4657

Books:

[1] Abdulkadir Muhammad, Hukum Perdata Indonesia print-5, Citra Aditya Bakti, Bandung, 2014

[2] Abdulkadir Muhammad, Hukum Perikatan, Citra Aditya Bakti, Bandung, 1992

[3] Achmad Busro, Hukum Perikatan Berdasar Buku III KUH Perdata, Percetakan Pohon Cahaya, Yogyakarta, 2011

[4] Idris Zainal, Ketentuan Jual Beli Memuat Hukum Perdata, Fakultas USU Medan, 2004

[5] Mariam Darus Badrulzaman, Aneka Hukum Bisnis, Alumni, Bandung, 2005

[6] Peter Mahmud, Metode Penelitian Hukum, KencanaPredana Media Group, Jakarta, 2005

[7] R. Soeroso, Perjanjian Dibawah Tangan Pedoman Praktis Pembuatan Dan Aplikasi Hukum, Ed. II, Sinar Grafika, Jakarta, 2010

[8] Yahya Harahap, Segi-segi Hukum Perjanjian, Second Edition, Alumni, Bandung, 1986 